\title{
About an A-Mazing Rubem Alves
}

\author{
Cláudio Carvalhaes*
}

\section{Resumo}

Este artigo introduz Rubem Alves em dois momentos: um primeiro como acadêmico e o segundo como poeta, escritor de contos e histórias infantis. Em seguida, o artigo continua apresentando alguns dos principais temas no trabalho segundo de Alves através da análise dos capítulos deste dossiê. Os autores deste dossiê mostram de maneira cativante muitos dos temas centrais do pensamento de Alves, como a beleza, a perda, saudades e poesia, e expandem seu pensamento através de várias correlações, seja de conceitos ou com outros autores. O que este artigo faz é oferecer uma avaliação crítica dessas análises e do próprio trabalho de Alves.

Palavras-chave: pensamento ocidental, beleza, perda, saudades, poesia

\section{Abstract}

This article introduces Rubem Alves' works in two moments: the one as a academic scholar and the second one as a poet, writer of short stories and children stories. Then the article continues by introducing some of Alves major themes through the analysis of the chapters of this dossier. The authors of this dossier beautifully show many of Alves themes, some of them are beauty, loss, saudades, and poetry, and expand his works through various correlations, either with concepts or other authors. What this article does is to offer a critical assessment of these analyses and of Alves' work itself.

Key words: western thought, beauty, loss, saudades, poetry

Rubem Alves: theologian, theopoet, religious thinker, psychoanalyst, philosopher, educator, sociologist, semiotician, political theologian, writer of children's stories, cook. A whole dossier could be written about each one of these expressions of the expansive Alves. Alves influenced generations of thinkers in Brazil and other countries and he now belongs in the pantheon

\footnotetext{
* É doutor pelo Union Theological Seminary União em Nova York, Universidade de Columbia, e Professor Associado de Liturgia no Union Theological Seminary. Email: ccarvalhaes@uts.columbia.edu.
} 
of the gods of words. From that place, he continues to bless us, challenge us, expand us, illuminate us and provoke wonder and awe in anyone who reads him.

As this dossier intends to deal with the latest work of Alves, it intends to analyze the ways in which Alves' latest production also carries a theory of religion. Towards the middle of his intellectual life Alves made a huge shift in his intellectual production, abandoning the academic format of texts with long paragraphs, complex language with many footnotes. He joined a different literary format, now made of short stories, chronicles, children's histories, all of it hinging on poetic texts ${ }^{1}$. This shift was intentional. He concluded that the formal intellectual hermetic language could never go beyond a very small circle of peoples. He realized that if any literature wants to make changes it has to be able to approach more people. This move had less to do with dumbing down complex forms of thoughts and theories and more to do with the fact that Alves knew that change could happen only if through emotions, with texts that deal with the mind but takes the itinerary either from or to the heart. Fundamentally, his psychoanalytical mind knew that a more poetic form of literature would allow him to access the human unconscious and offer ways to treat its dark side in a way that would invite readers to visit places inside of them that they not would have visited otherwise. In this way, Alves continues to give language to people to name and deal with their sadness, depression, loss, loneliness, grief and despair.

After having labored in heavy academic grounds and being very productive in his scholarly writings, Alves started to walk around with a pencil and a notebook in his pocket to not lose any insight, any idea that might want to show up to him. However, this new "academic" work was not a random take on whatever ideas he feels but rather, a very thorough development of these ideas without the academicisms that often cloud big ideas. Alves' major gift was to talk about complex and difficult issues in poetic ways. His last work is a maze of imaginaries, symbols, resources, figurings, and a variety of materials that, combined with his free imaginative mind and deep attention to the body, end up creating a vast and deep array of sources. He shows us

While Alves demonstrates a vast knowledge and inventiveness, it is fair to say that many of the children stories that Alves tells are not his own stories, but come from different sources that he doesn't mention. Just two examples: the story Strawberries, Os Morangos (São Paulo: Edicões Paulinas, 1933), is a version of the Buddhist story The Tiger and the Strawberry; the story The Scorpion \& the Frog (O Escorpião e a Rãa São Paulo: Edições Loyola, 1989), might be an Aesop's fable. 
his imagination liberated his readers by describing, expressing, pondering and wondering about our humanity.

That is what we see in the articles written for this dossier. They are a work of love, since the work of Alves has this power to move us deeply. We write because we feel some tenderness, some joy to be in the presence of one who cares for us, one who takes us by the hand and feels as our hearts feel. Like Jesus in the road to Emmaus, Alves fires our heart, making our minds fly and our bodies light.

This is a collection of literary testimonies that honors and blesses Alves for what he did for many of us. Among many others theologians, we were only able to continue our theological work because Alves showed us a new way to think and believe, he gave us permission to err, to try and fail, he loosened up our fearful minds, he taught us to speak in tongues, and to discover our bodies. He opened up a new lexicon, gave us sources that we never thought could be combined and spoke in a manner that made us walk in clouds. After reading him it was hard to listen to any other preacher. For many of us, after having had our faith stolen by fundamentalist Christian churches, God became possible again, and even possible to not be possible anymore. But more importantly to our faith, Alves gave us joy, imagination, poetry, utopia, affection, beauty, playfulness and magic! We all wanted to go where he was and also be like Alves. Many of us tried to write like him without having gone through all the readings and thoughts he did, the high mountains and the deep valleys he underwent. Besides, who of us had the gifted heart and mind he had? However, this dossier has wonderful texts that help us expand our vision of Alves. Let us consider some of the major themes raised by these essays.

In The Colors of Twilight: Fables, Theology, and Literature in Rubem Alves, Anaxsuell Fernando gives a solid itinerary of Alves' thinking from his early works around liberation theology, moving though science and sociology and towards his final production with children's stories. Fernando helps us understand Alves' thinking by pairing his thinking with the daily-evening thinking of Gaston Bachelard (1884-1962). This metaphor describes Bachelard's daily thinking as marked by his love for objective knowledge, epistemology, rationalism and scientific empiricism. The other side of Bachelard, the Bachelard of the evening thinking is marked by imagination, poetry and art, forms of knowledge that cannot be captured fully or are in service or saying something that cannot be said. This is an apt metaphor to the thought of Alves. Alves' 
thinking also carries this double movement, engaging his daily (early) work with science, theology, sociology and its proper rules (his book Philosophy of Science: Introduction to the Game and its Rules) as well as his night (later) writings on poetry, life, elderly years, desires, children's stories, short stories, the quotidian, art and so on. However, I'd suggest that Alves' thinking is more nuanced than a sharp daily-evening binary as suggested by Anaxsuell. Alves' idea is to confound these distinctive fields by blending them. He carries the dawn of life, the very chiaro-escuro of thinking-feeling that is always blurred, always dying and holding something anew, leaving us with the expectation of the proximity with beauty, pregnant with surprises. Moreover, his conceptual thinking is always filled with images, his analytic thought moving with a fluidity that will keeps on becoming more disentangled, and thus free, from the severity of dry terms. Also, Alves' children's stories deal with the escuro of the lives of the kids bringing light to it in ample ways. Alves' thought, including his late writings, can only survive the forgetfulness of time because he works from strong theoretical frameworks of knowledge that moves. In this way, Anaxsuell is right when he suggests that Alves arrived at a higher point because of his ability to walk through bridges and move between different objective and subjective worlds. In this free crisscrossing, bold as he is, Alves discovered one thing that sustains him: beauty. In that way, he became an evangelist of beauty, visiting people's worlds and telling them about the deadening world they live in without beauty and freedom. That is what he wanted adults to discover about kids and kids to be able to name that beauty before they are cut off from the objective, sometimes lifeless world of the adults.

In the article The Moment of Pleasure and Joy: a Way for the Resurrection of the Bodies in Rubem Alves, Douglas Rodrigues da Conceição focus on the book Variações Sobre o Prazer ${ }^{2}$ (ALVES, 2004, p. 8). The author works from the edition of 2011 but forgets to mention that this is a reedition of a 2002 book called $A$ Book Without End (ALVES, 2002). In this book Alves plays a game saying "Let us pretend that we know we have only one more year to live. How would we live knowing that time is so short?" When he considers the rest of one's life he considers the theme of pleasure. The old days and the proximity of death attunes his heart to what really matters in life and for him what matters is pleasure, and pleasure is mostly in the things and

2 The title of the book can be translated as Variations on Pleasure. 
people around him. To understand Alves' notion of pleasure, one needs to understand his books O Suspiro dos Oprimidos (The Sights of the Oppressed) and Variacoões Sobre a Vida e A Morte ou o Feitiço Erótico-Herético da Teologia (Variations of Life and Death or the Erotic-Heretic Spell of Theology) where Alves work with the superstructures that constitutes society (power and language) and see in the daily "discourses" of pleasure/pain the possibility to actualize life. In The Sights of the Oppressed, Alves says that "language is the collective memory of society" (ALVES, 1999, p. 15), and this memory must be re-membered (anamnesis) in the daily actions of life. In this way Alves' notion of pleasure, as correlated to memory, is fundamentally influenced by both Saint Augustine and Jean Calvin and their notion of sacrament as "a visible sign of an invisible grace." For Alves, the joy of life is in finding pleasure or being found by beauty. This comes from the task of remembering the beauty, thus the pleasure that is hidden in plain sight in cooking, in food, in fruits, a song, a work of art, in the garden, etc. Alves' notion of pleasure is rarely associated with sex/sexualities and this is an interesting lack of his discourse since he criticized the Puritan western discourse, and he helped theologians to discover own their bodies ${ }^{3}$.

In The Song of the Enchanted Bird: Religion As "Saudade" in Rubem Alves, Gustavo Claudiano Martins focuses on a word that infuses all Alves' oeuvre: saudade. It is hard to translate saudade. It is a mix of missing, void, absence and lack. It can also be understood as the African notion of banzo. Saudade is a Portuguese-colonized cultural mark on the Brazilian soul. Portugal's music fado is nothing else than sad songs of love that express something that was lost, missed in life and how this loss has provoked a hole, a lack in the heart of the lover. Alves is deeply influenced by the Portuguese poet Fernando Pessoa who is himself a poet of saudade. Alves will relate his understanding of saudade to religion through the work of Feuerbach. Feuerbach will say that religion is a projection of the human soul unto something that $\mathrm{s} / \mathrm{he}$ is lacking. No wonder Alves will quote Paul Válery so many times: "What would be of us without the help of that which does not exist." As men-

To read a critical assessment of Alve's work on the bodies, see, in English: Cláudio Carvalhaes, "The Poor Don't Have Sex —Liberation Theologies and Sexualities." In Pressing On: Next Generation of Indecent Theologians. Ed. Nestor Miguez and Nicolas Panotto (New York: Palgrave Macmillam, 2016). In Portuguese, see: Cláudio Carvalhaes, "O Pobre Não Tem Sexo: A Ausência do Corpo e da Sexualidade na Construção da Subjetividade na Teologia da Libertação na America Latina." In Sexualidade-Abordagem Bíblica, Teológica e Pastoral, Carlos Eduardo Calvani (Organizador) (Fonte Editorial, Sao Paulo, Brazil, 2011). 
tioned before, Alves was also influenced by Augustine, Calvin and Zwingli, mixing an understanding of the sacrament of the eucharist as the presence of an absence. What we celebrate at Eucharist is the presence of an absence, God, who is not there anymore but by whose memory we can engender new worlds within and outside of ourselves. Alves will also show his deep Christian formation when he criticizes the philosophical tradition in constantly attempting to turn humankind into beings towards knowledge, saying that we are made of feelings, and the chief feeling among them, saudade, our feeling of lacking. Human beings have lost God in paradise but keep trying to name that loss without succeeding. No wonder one of the most remarkable metaphors for life in fullness for Alves is the garden. However, not an idealized garden, but one made of soil, work, sun, presence, water, seeds, sweat, fruits, flowers and produce to bring to the table. In the garden we work on that which we lost inside of us. At some point, Alves says he doesn't want to do theology anymore because if we say what God is, we will turn God into something like any other object and god will disappear. Alves moves towards a certain use of the via negative theology, saying not what God isn't, but rather, what God has become in what we miss, lack, long, both in the past, but also in the present and in the future. Martins rightly calls this sense of saudade an "anthological saudade," as the garden where we hold on to our utmost longings. Nonetheless, if we stretch this ontological saudades, we see that Alves continues the same project of the Western thought by associating feelings of loss and lack to that of an impossible knowledge. God continues to be this ontological space but now with a different name. What disturbs the Christian churches and its theologies is Alves' notion of Christianity's whole absence. Christianity is a religion of an absence since Jesus has died and resurrected. In both ways, Jesus is only present by way of its absence. Perhaps influenced by the suffering in Christian atonement, Alves says that what makes us create is suffering. Suffering makes us alive since it connects us with time and we have to think to find a way around our pain. It seems like the "redemptive" way of life for Alves can only come through suffering, more than the mere absence of health. Moreover, it is Augustine and all of the Christian mystics who see God as the deepest desire of the human soul that will mark Christians. To desire God is to want that which we don't have, or lost: God itself. This sense of lack is a tradition of the Greeks in Christian thought and will be developed in more complex ways by Sigmund Freud and later in Jacques Lacan where desire is as that which 
one lacks (manque $)^{4}$. Alves' notion of desire has resemblance to what Freud and also Lacan defines as lack. Following from the footnote, we can say that Alves' "this" or "that" can be the marks of we lack. Thus, this lack is what creates desire which can only be named through this and that in fractured, limited ways, never fully. Gilles Deleuze will say that this correlation of desire-lack that plagued us has been brought to us by the Greeks through Christians and has formed the Western world through a Cartesian development of thought/knowledge/pleasure where thinking is also associated with desire ${ }^{5}$. If we concur with Deleuze's assertion, Alves will continue this tradition by associating desire to manqué through the instrumentalization of our feelings/thoughts. The Cartesian structure continues unhinged in Alves' thought. Thus, calling God beauty, lack or saudades, the ontological thought of Alves does not move Aquinas' metaphysical "unmoveable mover" God. It does however, provide a different color. From this ontological saudade, Alves provides a new window to the same God, a God that looks to us from the abyss, from the deep seas, from the open cages, telling us we are that which we have saudades, either from past or from the future.

In Out of Beauty there is no salvation: Rubem Alves's movement from faith-engagement to theopoetry, Kenner Terra and Rainerson Israel follow the same path of Martins, now using beauty as Alves' movement from theology to poetry. Terra and Israel start by naming some of Alves' intellectual influences: The Frankfurt School, Theory of Dependance, Luther, Barth, Bonhoeffer, Tillich, Richard Shaull, Wittgenstein, Malinowski, Huizinga, Hesse, Marx, Freud, Nietzsche, and Feuerbach. When they mention Alves' "Messianic Humanism," they are alluding to the fact that God is a humanizing factor, a way of engaging God in politics where the body, its eroticism and pleasure are also a fundamental part of the transformation of society. Alves' expansive ways of seeing social transformation are not only tied to social political economic analysis, but fundamentally linked to beauty and happiness. This was not received well by some liberation theologians such as Hugo Assman. The fact that Alves advocated for a messianic humanism was still related to what

4 Lacan will say that "Desire is a relation to being to lack. The lack is the lack of being properly speaking. It is not the lack of this or that, but lack of being whereby the being exists." In Lacan, Jacques, Seminar of Jacques Lacan, Book II, The Ego in Freud's Theory and in the Technique of Psychoanalysis, 1954-1955, Jacques-Alain Miller (Editor), Sylvana Tomaselli (Translator), (New York: W. W. Norton \& Company, 1991), 223.

5 See the work of Beckman, Frida, Between, Desire and Pleasure: A Deleuqian Theory of Sexuality (Edinburgh: Edinburgh University Press, 2013). 
was coming, to the arrival of the "new Man," even though this arrival was accompanied to other historical human resources, namely joy, eros, grace, beauty, and other values that should be considered for this transformation. The body became the locus of this new epistemology and one needs to pay attention to it. Alves harshly criticized the "Protestantism of the Right Doctrine," which colonizes the body and the mind of the believer. Alves' wanted to be free from this brutal and violent grasp. His writings foment an autonomy of the self/body that was new for theology. Theology thus becomes a place for the body to make poetry, to name its hopes and longings, said in prayer. Poetry, with all its fluidity and attention to different things, runs against the stiff order of things. The eyes of the poet are always elsewhere which for those who cannot see, is frightening. So the poets are accused of being crazy! Thus, faith is an exercise in being a fool. Perhaps in no other Brazilian thinker one can see more extensively the deep connection between the theologian and her necessary foolishness.

Luana Martins Golin, in The Theopoetics of Rubem Alves, delves in Alves's last works to see how the literary work of Alves speaks more fluently, even if in more complex and in untenable ways, about God. She follows Alves words when he said "to think about God I don't' read theologians I read the poets." Words together are forms of spell and from the witch's cauldron we get the best ways to unlearn about God. The image of the cauldron is one among many others in the kitchen vocabulary of Alves. Alves uses dishes and soups and food and taste to talk about life and God. Alves uses the word knowledge to expound two meanings: to know and to taste. Thus, to know God one has to taste God, not only in the delightful tastes of poetry but in the concrete and the delicious tastes of real food. But more than that, one needs to learn how to prepare the food. The movie Babette's Feast becomes a recipe for theology. Babette is a magical cook, turning into reality what isn't, awakening people's hearts into realities that wasn't. Babette must be Alves' favored theologian since she knows how to love, how to help people to love and how to resurrect through cooking and eating. Babette is a fantastic poet of witch craft. For "all poetry is an act of witchcraft whose purpose is to make present and real that which is absent and has no reality," says Alves. For him poetry works with the most potent material we have: words. Words that create symbols, visions, feelings, worlds! The same way that saudade, beauty and pleasure are fundamental places to name the unnamable, to show the primordial absence/lack that lives in us. Inside of us there is a 
word that wants to utter the primordial word, the most fundamental name. Silence is what exists prior to the words and from where words sprang trying to name that silence that is ultimately unnamable. This place is also God, fundamentally unsayable and ultimately unsaid. Poetry, as well as theology and art, have to return to that abyss, to that silence, to that primordial place where the first creating word appeared. Golin connects words with beauty and eucharist, themes we have already mentioned here. Alves' theology is theophagic, or in a Brazilian manner: anthropophagic. He says: "He who reads drinks the blood of those who wrote. The ritual of reading is, like the Eucharist, an anthropophagic meal." Anyone who enter into Alves' maze, runs the risk of drinking the blood and eating the flesh of somebody else, perhaps even his own.

In this rich contribution, Leopoldo Cervantes-Ortiz wrote To Play Seriously All the Time: The Transgressive and Playful Theology of Rubem Alves, and bring to us the rich ways in which Alves has provoked a schism within theology, showing us a new way that theology could be done. We tend to run the risk of missing or taking for granted, or dismiss the immense work Alves did to free us all. His work in breaking from unbreakable forms of knowledge and challenging violent traditions, with the risk of losing his own life, cannot be taken lightly. As Cervantes-Ortiz properly says, "Alves left forever the ghetto of the churches to enter fully in the terrain of the imagination." Even when we think about the "last" writings of Alves, we cannot forget how he created a path by himself, to create something new, and how this path made possible for this thinking to arrive later where it landed. It is the hard, deep, committed theoretical work of his beginning that allowed him to be free later in his life. Once Alves said that to do a doctorate one has to like boring things, learning to read dry, difficult texts. And he did it. He delved into the whole western tradition digging deeper. Perhaps it was from this bitter taste of knowledge that Alves learned how to prepare savory texts for knowledge. In this article, we see how the aesthetics of Alves informs his ethics and not the other way around. This is perhaps the most radical difference between Alves and other liberation theologians. While most theologians focus solely on the ethical dimensions for transformation, very often forgetting the aesthetics of this process, Alves shifts its terms and says that without beauty there is no salvation, because without aesthetics there is no way ethics can do its work alone. Alves teaches us this because we are made of beauty and desire for happiness and not of ethical demands 
for what is right. Our very relation with God is made of beauty and God's presence is that which humanizes, and makes the life of people beautiful/ just. Perhaps this is the major lesson politicians and political theologians should learn from Alves. Cervantes-Ortiz also names a host of influences in Alves' thinking: Guimarães Rosa, Gabriel García Márquez, Octavio Paz, Robert Frost, Paul Valéry, Fernando Pessoa, Cecília Meireles, Adélia Prado, Feuerbach, Leszek Kolakowski, Peter Berger, Thomas Luckmann, Norman O. Brown, Nietzsche, T.S. Eliot, Hermann Hesse and so on. From Eliot and Frost he makes fundamental companions in many of his books. From Hesse, he takes a whole metaphor: The Glass Bead Game, that defines Alves' very framework of theology. From this article, we also gain a complex thinker who was also a player. A serious player of "the game of science, education, poetry," but also of theology, psychoanalysis, semiotics, sorcery, music and with/witch craft. "Everything," says Cervantes-Ortiz, "saying that he had arrived late in the bosom of poetry."

Last but surely not least, José Lima Júnior writes a wonderful article called Thus Kissed Benjamin. It is an article that focuses on Alves' book' Somebody Asked Me If I Believed in God, from 2007. The reasons for this choice are personal and also related to the ways in which form and content are unequivocally intertwined in this book. Lima is a semiotician himself and treats every aspect of the book with eloquence: the dedication page, the table of contents, the story before that, each chapter, the back and cover and so on. Everything for Lima has a movement between communication and expression, the closest place where poetry happens. In this book, Alves invites us into a anthropophagic movement where he shows us what and who he ate as we eat him and everybody else he has eaten. However, this anthropophagic ritual, as Lima sees it, is "a pneumatic movement from Alves, a poetic discourse about God that is better drawn to be liturgical eucharistic theologies." These prayers are done at the abyss, where Alves build his altars with music and poetry. These forms of art, as Alves says, illuminates and warms his face but doesn't do anything to the abyss. Lima proceeds in the article offering three amazing reasons why Alves uses the name Benjamin as a form of alter-ego to tell the 21 stories of the book. To reduce his explanation here is to reduce the whole work of Lima and Alves as well. Also, the rest of Limas' article is impossible to describe. This impossibility serves as an invitation for you to learn Portuguese and read Alves, and Lima, and discover the fantastic ways these two writers can make us imagine and expand ourselves. 
As I move towards the end, let me connect Lima's notion of Alves' text as liturgical eucharistic theologies and Alves own naming and living near the abyss with music and art. I remember the liturgical theologian Aidan Kavanaugh who, quoting Urban Holmes, says that "liturgy leads regularly to the edge of chaos, and from this regular flirt with doom comes a theology different from any other" (Kavanagh, 1992, p. 73). In was in this flux and crisscrossing of references that I understood Kavanagh's notion of abyss and Alves "liturgical theology." Alves liturgy/artistic ritual always takes us to the abyss so we can look into it. There, we cannot keep staring into the abyss and so we create liturgies to live and play. For Alves, music and art are the preferred artistic liturgical tools. However, once we see the abyss we cannot forget it, or run away from it. Flirting with doom, we are changed forever. Our theologies will be forever different as well and different from before. That is what Alves does. He realizes that formal theologies are nothing else but the constant attempt to avoid this flirtation with the abyss, to pretend that we are away from the precipice, that we can prevent from falling and that we can change the precipice itself. Formal theologies are nothing but mute cries translated in words that desperately try to evade its edges, circumvent its reality and avoid emptiness. Alves helps us be friends with the abyss, I seriously play, knowing that nothing we do will prevent us from falling into its abyssal mouth. At the abyss, we are called to be artists, poets, musicians, dancers, carriers of joy! Before we fall, we must reinvent the eternal at every corner, sing and play, read and eat, have fun, tell stories, spend time with children, love. That explains why Alves' desired epithet was a blessing and a demand to us all: "He had a love affair with life."

I finish invoking Alves sacramental notions of anthropophagy and presence/absence. By reading Alves, we consume him! We eat him! He now belongs to me! I now am strengthened by his power, his beauty, his strength. Second, he continues to be fully present in us by way of his absence. And fully absent by ways of his present writings. After all his life and all these years since he died, he has finally become the main cook at Rubem's Feast, the strawberry we found at the abyss. And from that abyss, he will keep playing and doing poetry among us all and within each of us. He has become the fire that illuminates and warms us, a fire that is not consumed. 


\section{Bibliography}

ALVES, R. A. Variações sobre o prazer. São Paulo, SP: Planeta, 2004.

ALVES, R. A. Livro sem fim. São Paulo, SP: Edições Loyola, 2002.

ALVES, R. A. O suspiro dos oprimidos. São Paulo, SP: Paulus, 1999.

KAVANAGH, A. On liturgical theology. Collegeville, EUA: Pueblo Book, 1992. 